\title{
Sami Language
}

National Cancer Institute

\section{Source}

National Cancer Institute. Sami Language. NCI Thesaurus. Code C161908.

A group of Uralic languages spoken by the Sami people in Northern Europe. 